\title{
Prey and seasonal abundance of killer whales at Subantarctic Marion Island
}

\author{
RR Reisinger*, PJN de Bruyn, CA Tosh, WC Oosthuizen, NT Mufanadzo, MN Bester \\ Mammal Research Institute, Department of Zoology and Entomology, University of Pretoria, \\ Pretoria, 0002, South Africa \\ * rrreisinger@zoology.up.ac.za
}

\section{ABSTRACT}

To understand the role of killer whales in marine ecosystems, descriptions of their diet are vital, yet this aspect is poorly known in Subantarctic killer whales. During 823 sightings of killer whales at Subantarctic Marion Island (2006 - 2009) we recorded 48 predation events; in only 10 cases could prey be identified. Killer whales fed on fur seals, elephant seals and penguins. Constant effort (dedicated) observations (259 hours, 2008 - 2009) showed that killer whale abundance, which peaked in September - December with a secondary peak in April - May, is linked to the abundance of seals and penguins.

KEYWORDS: Orcinus orca, seals, diet, foraging, Southern Ocean, occurrence cycle 


\section{INTRODUCTION}

Killer whales (Orcinus orca) exhibit wide variation in foraging ecology throughout their range (and even locally), with distinct populations specializing on certain prey types (reviewed by Baird 2000). They are apex predators and their documented prey include a variety of taxa including cephalopods, bony and cartilaginous fishes, reptiles, birds, and mammals (Hoyt 1990, Jefferson et al. 1991). As such, killer whales can have important top-down effects on marine ecosystems (Bowen 1997; see also Springer et al. 2003) and the diversity of their prey means they can potentially influence ecosystem structure and function at various levels (Ford and Ellis 2006).

In the southern Indian and Atlantic oceans, killer whales have been poorly studied. At the Crozet Islands killer whales were observed feeding on seals, penguins, fish and large cetaceans (Guinet 1992) and at Punta Norte, Argentina, killer whales are frequently observed attacking seals, but also to some extent feed on penguins and fish (Lopez and Lopez 1985, Hoelzel 1991, Iñíguez et al. 2002). At Marion Island (MI), opportunistic studies have investigated killer whale population structure, local movements and social structure (Condy et al. 1978, Keith et al. 2001, Pistorius et al. 2002, Tosh et al. 2008). A population size of 42 animals was recently estimated using mark-recapture methods and 37 individuals were photographically identified (Reisinger et al. in review). As at the Crozet Islands and Punta Norte (situated at similar latitudes), killer whales are sighted year-round at MI, but their abundance peaks in the austral summer, arguably as a function of the seasonal haulout of elephant seals (Mirounga leonina) and certain penguin species (Condy 1978, Keith et al. 2001). Seasonal co-occurrence with potential prey species is speculative and has not been verified using dedicated observational sampling techniques. Opportunistic observations of killer whale predation at MI (Condy et al. 1978, Keith et al. 2001) suggest that they include a combination of seals and penguins in their diet.

MI supports increasing populations of both Subantarctic (Arctocephalus tropicalis) and Antarctic fur seals (A. gazella) with total pup productions of 16045 and 759, respectively, in 2004 (Hofmeyr et al. 2006). The elephant seal population appears to be increasing and current pup production is approximately 520 (de Bruyn 2009, McMahon et al. 2009). King 
penguins (Aptenodytes patagonicus) numbered 65000 breeding pairs in 2008; gentoo penguins (Pygoscelis papua), macaroni penguins (Eudyptes chrysolophus) and eastern rockhopper penguins (E. chrysocome filholi) numbered 1 100, 290000 and 42000 breeding pairs, respectively, in 2008 (Crawford et al. 2009). Clearly, these large populations provide substantial potential prey for top-predators such as killer whales.

This study aims to describe the diet of killer whales at MI, based on direct observation, and to investigate their seasonal abundance at the island in relation to known prey species that occur in this region.

\section{METHODS}

\section{Study site}

Subantarctic MI $\left(46^{\circ} 54^{\prime} \mathrm{S}, 37^{\circ} 45^{\prime} \mathrm{E}\right.$, Figure 1) is the larger $\left(296 \mathrm{~km}^{2}\right)$ of a pair of islands comprising the Prince Edward Islands (PEIs) group. It is situated in the southern Indian Ocean with the nearest landmass being the Crozet Islands (950 km to the east) in practically the same latitude. The interplay between the Antarctic Circumpolar Current and the prominent bottom topography of the South West Indian Ridge results in productive turbulent water masses around the PEls (Ansorge and Lutjeharms 2005), sustaining the numerous mammal and bird species that breed there.

\section{Field methods}

Land-based, opportunistic sightings of killer whales at MI were recorded between April 2006 and April 2009. For each sighting, location, group size and age- and sex-class composition of the group, as well as direction of movement was recorded. Sex was determined based on size and shape of the dorsal fin, relative body size and close association with calves (adult females). Distance from shore was recorded following Condy et al. (1978): zone 1: within 5 $\mathrm{m}$ of shore; zone 2: 5-100 $\mathrm{m}$ from shore, usually extending to the first kelp belt (Macrocystis sp.); zone 3: 100-500 $\mathrm{m}$ from shore, usually extending to the second kelp belt; zone 4: beyond $500 \mathrm{~m}$ from shore. As many individuals as possible were photographed at each sighting and notes were made regarding the animals' behaviour. Predation events were noted when killer whales were seen with prey in their jaws, or when prey remains were 
visible at the sea surface immediately following killer whale observation (usually giant petrels [Macronectes spp.] fed on these).

Additionally, land-based "dedicated observation sessions" were performed between May 2008 and April 2009, during which one of two trained observers remained at set observation points and visually searched for killer whales for a pre-determined length of time. The same data were recorded as for opportunistic sightings, as well as Beaufort sea state. Figure 1 shows the distribution and relative population sizes of fur seals (Hofmeyr et al. 2006), southern elephant seals (de Bruyn 2009), king penguins (Crawford et al. 2003a) and macaroni penguins (Crawford et al. 2003b) at dedicated observation sites. Rockhopper penguins are distributed relatively evenly along Ml's coast (Crawford et al. 2003c) and gentoo penguins nest in small colonies (on average, less than 40 pairs) at few locations (Crawford et al. 2003d). Observation locations were thus sited at certain breeding colonies of all seal and penguin species. Short-term (one day) observations of the inshore movements of killer whales at MI (Pistorius et al. 2002) suggest that groups of killer whales patrol large sections of the coast, and that they are active at all (daylight) hours (Keith et al. 2001), increasing the likelihood of sighting animals from single observation points.

Observation sessions were of two types:

1) In order to investigate the seasonal abundance of killer whales, between May 2008 and April 2009, 93 short (2-3 hours) observation sessions were performed from the same point at Rockhopper Bay, MI (Figure 1), totalling 249 hours (approximately the same effort monthly, except for April 2009; Figure 2). Observation sessions were performed at regular intervals throughout each month, and at approximately the same time of day. Because the probability of sighting killer whales far from shore was potentially influenced by sea state, we limited our analysis to sightings of groups within $100 \mathrm{~m}$ from shore (zones 1 and 2). We considered the probability of sighting groups at this distance not to be influenced by sea state. Repeat sightings of a group during a session were also eliminated. These were identified by the group size and composition, and direction of movement. 
2) 46 long (10 hours - uninterrupted) observation sessions were performed at various points (Figure 1) around the island more than once a week between August 2008 and April 2009, totalling 460 hours.

\section{RESULTS}

\section{Predation}

Between April 2006 and April 2009, a total of 823 killer whale sightings were made during opportunistic and dedicated observations. Forty eight predation events were recorded. For 38 events the prey could not be identified, but in 10 instances the prey was unequivocally identified from photographs. Penguins (unknown sp.) were killed by killer whales on three occasions, a king penguin was killed and eaten on one occasion and a macaroni penguin on one occasion. Elephant seals were killed twice (one a subadult, the other a subadult or adult female; Figure 3) and Subantarctic fur seals were killed on three occasions (all pups). Killer whales unsuccessfully pursued a subadult elephant seal as well as an adult female Subantarctic fur seal. While killer whales were not directly observed predating on Antarctic fur seals, unknown prey was consumed at Watertunnel Beach (Figure 1), the site of the largest Antarctic fur seal breeding colony on the island, on more than one occasion. Three observations were made of killer whales interacting with large cetaceans (a southern right whale, humpback whales and a group of unidentified whales): on each occasion the killer whales moved towards the whales and swam alongside or around them, but did not make observable physical contact with the whales.

\section{Seasonal abundance}

During 93 dedicated observation sessions at Rockhopper Bay (April 2008 - May 2009), killer whales were sighted 49 times (repeat sightings per session excluded; zone 1 only). The maximum number of sightings per month was 12 (November 2008) and no killer whales were sighted in July 2008 and January, February and March 2009. Maximum sighting frequency was 0.57 groups.hour $^{-1}$, during May and November 2008 (Figure 2) and mean monthly sighting frequency was 0.21 groups.hour $^{-1}$. Overall, monthly sighting frequencies differed significantly (Kruskal-Wallis test, $p<0.01$ ) Killer whale sighting frequency showed a clear peak in May 2008 and between September and December 2008; Mann-Whitney pair- 
wise comparisons are shown in Table 1. For all sightings from April 2006 - April 2009, group size ranged from 1-13 individuals with a modal group size of 3. Group size frequency distribution of killer whales sighted in the summer peak of sighting frequency (SeptemberDecember), autumn peak (April-May) and the rest of the year (January-March and JuneAugust) is shown in Figure 4. A Kruskal-Wallis test showed slight significant ( $p=0.03$ ) difference between the frequency distribution of the three periods (Figure 4). Two-sample tests for equality of proportion showed significant $(p<0.05)$ differences in four of the 39 pair-wise period-group size frequency comparisons (Figure 4), but only highly significant differences $(p<0.01)$ between the sighting frequency of one individual in the summer and autumn peaks and between the summer peak and the rest of the year.

\section{DISCUSSION}

\section{Predation}

Killer whales were observed preying on two of the three seal species occurring at $\mathrm{MI}$ and two of the four penguin species and these observations are similar to data for "transient" killer whales in the eastern North Pacific and seemingly similar to populations at the Crozet Islands and Punta Norte. It is unknown whether killer whales at MI include fish and cetaceans in their diet.

In the eastern North Pacific foraging observations and stomach content analyses show that "transient" killer whales feed primarily on harbour seals (Phoca vitulina) but include a variety of other pinnipeds, cetaceans (including large whales) and seabirds in their diet (Ford et al. 1998). Iñíguez et al. (2002) reported that killer whales in Northern Patagonia feed mainly on southern sea lions (Otaria flavescens) (85.7\%) but also on elephant seals (3.9\%), Magellanic penguins (Spheniscus magellanicus) (3.9\%) and fish (6.1\%). In southern Africa the 26 stomachs of killer whales examined (mainly from animals taken during whaling operations) contained primarily marine mammal remains ( $84.6 \%$ of stomachs) followed by fish (23.1\%), squid (3.8\%) and seabirds (3.8\%; Best 2010). While seabirds may not represent an important food source in the eastern North Pacific or South African waters (Williams et al. 1990, Ford et al. 1998), penguin populations in the Southern Ocean - often locally numbering several hundred thousand birds - may be more important for killer whales at 
these localities. Antarctic "Type B" killer whales apparently feed mainly on seals but also take penguins (Pitman and Ensor 2003, Pitman and Durban 2010).

Killer whales in the vicinity of MI (i.e., outside the fisheries exclusion zone of 8-12 nm around the PEls [de Villiers and Cooper 2008]) are frequently observed depredating Patagonian toothfish (Dissostichus eleginoides) during demersal longlining operations (Kock et al. 2006, Williams et al. 2009) and further photo-ID investigation should be directed at determining whether these individuals also feed on seals and penguins close inshore. Equivocal interactions were observed with large cetaceans and it is unclear whether killer whales prey on large cetaceans at MI as they do at the adjacent (950 km) Crozet Islands, directly to the east of Marion Island (Guinet 1992, Guinet et al. 2000).

Unfortunately, describing the diet of killer whales based on observations of predation events has important limitations: such observations are relatively rare, observations include mainly larger prey consumed at or near the surface, reflect dietary habits only in the area where observations are made (in this study, near inshore), it may be difficult to distinguish prey killed and consumed from prey killed and left, and the dietary habits observed may be short term (Ford et al. 1998, Krahn et al. 2008).

\section{Seasonal abundance}

Structured dedicated observation sessions (this study) confirm the previously shown peak in killer whale occurrence at MI between September and December (Condy et al. 1978, Keith et al. 2001), and link it to the breeding timing of seals and penguins at the island (Figure 2). Our dedicated observations confirm a secondary peak during April - May, linked to the occurrence of fur seal pups in inshore waters, and without the potential effects of observer effort bias present in previous studies. The occurrence and distribution of killer whales has been linked to the abundance of prey resources before (e.g., Nichol and Shackleton 1996, Similä et al. 1996) and to seasonal breeding in seals (Hoelzel 1991, Iñíguez 2001, Bolt et al. 2009).

Elephant seals have a median haulout date of 15 October (Kirkman et al. 2004) at MI and give birth within a week after arrival (Laws 1956). Pups wean at an age of 21 days and swim 
close to shore before dispersing in November and December (Wilkinson and Bester 1990). Weaned elephant seal pups are presumably profitable prey for killer whales as they would be relatively easy to catch and safe to handle, with up to $25 \%$ of weaned pups taken off a particular beach at Possession Island, Crozet Islands (Guinet et al. 1992). The median arrival date of king penguin adults at colonies is in November (du Plessis et al. 1994), macaroni penguin median arrival is in mid-October (Crawford et al. 2003b), rockhopper penguin arrival in early November (Crawford et al. 2003c) and gentoo penguin in late June (Crawford et al 2003d). The first three species breed in large numbers (Crawford et al. 2003) and their densities in inshore waters are high as they arrive to breed at MI. Their timing of breeding coincides with the peak occurrence of killer whales. Gentoo penguins are present in relatively small numbers (Crawford et al. 2003), and likely do not represent an important prey source for killer whales at this site. Antarctic fur seals and Subantarctic fur seals have median parturition dates of 6 and 18 December, respectively (Hofmeyr et al. 2007) and thus prior to this, large numbers of fur seals arrive to breed, providing prey for killer whales. Antarctic fur seal pups wean at an age of 112 days and Subantarctic fur seal pups at approximately 300 days (i.e., in March and October of the following year, respectively; Kerley 1985), whereafter they disperse. Pups of both species start swimming close to shore especially in February (Kerley 1983). The availability of large numbers of fur seal pups inshore likely explains the secondary peak in occurrence of killer whales in April - May.

The observed group sizes (Figure 4) of killer whales at MI are consistent with earlier observations for the island (Condy et al. 1978, Keith et al. 2001, Tosh et al. 2008), as well as for populations of pinniped-eating killer whales elsewhere. This is likely an optimal group size for maximizing energy intake in such populations (Baird and Dill 1996). The modal group size observed ( 3 individuals) is comparable to average group sizes of 4.2 (Condy et al. 1978), 3.6 (Keith et al. 2001) and 3.4 (Tosh et al. 2008) reported previously at MI, and 3.2 (modal group size of 2) at Punta Norte (Lopez and Lopez 1985) and modal group size of 3 at Vancouver Island, British Columbia (Baird and Dill 1996). Larger group sizes are reported for piscivorous populations (e.g., Bigg et al. 1990, Pitman and Ensor 2003, Dahlheim et al. 2008) and Burdin et al. (2007) showed significant differences between group sizes of mammaland fish-eating killer whales in the Russian Far East. The largest groups observed at $\mathrm{MI}$ included identified individuals which were mostly observed separately on other occasions 
(Mammal Research Institute, unpubl. data), indicating temporary interactions of smaller groups, likely for socializing and perhaps cooperative hunting (Baird and Dill 1996). This illustrates that, albeit for killer whales in different habitats and aquatic ecosystems, a stable group size occurs in predominantly pinniped-eating populations, governed by the energetic limitations of foraging on marine mammal prey (Baird and Dill 1996). The highly significant differences between sighting frequencies of single individuals during the summer sighting peak, autumn peak and the rest of the year, are likely related to the social role of "roving" males as identified in British Columbia (Baird and Whitehead 2000). Such males disperse from their maternal pod and appear to spend some of their time alone, occasionally associating with groups that contain potentially reproductively receptive females. Such associations may be more common at certain times of the year in the MI population, explaining the change in sighting frequency of solitary killer whales.

\section{CONCLUSIONS}

Killer whales at Subantarctic MI predate on elephant seals, fur seals and penguins but it is unknown whether other prey species, such as cetaceans and fish, may be included. Their temporal abundance at the island is linked to the near-/onshore temporal abundance of the observed prey species. Our findings are similar to those for killer whales at the Subantarctic Crozet Islands and Punta Norte, Argentina. Despite the limitations of the current study, it provides systematically collected information about the diet of a poorly known population of killer whales.

For the informed management and conservation of killer whale populations as well as their prey, attempts to elucidate the diet of killer whales at MI should continue, employing the current observational methods (which are neither costly nor invasive) as well as methods such as fatty acid and stable isotope analysis (e.g., Herman et al. 2005). Of particular interest is the frequency of occurrence of particular prey types and the potential impact of killer whales on populations of their prey, especially seals. Future research should also be directed at the large-scale movements of killer whales, using continued photographic identification at various localities and satellite telemetry (e.g., Andrews et al. 2008), as well as their stock structure in the region, using genetic methods (e.g., Hoelzel et al. 1998). 


\section{ACKNOWLEDGEMENTS}

We thank the South African Department of Environmental Affairs for providing logistical support within the South African National Antarctic Programme and the Department of Science and Technology (administered through the National Research Foundation) for funding the marine mammal monitoring programme at MI. Various overwintering and relief expedition members recorded their sightings and provided photographs. Two anonymous reviewers provided useful comments on this manuscript.

\section{REFERENCES}

Andrews RD, Pitman RL, Ballance LT. 2008. Satellite tracking reveals distinct movement patterns for Type B and Type C killer whales in the southern Ross Sea, Antarctica. Polar Biology 31: 1461-1468.

Ansorge IJ, Lutjeharms JRE. 2005. Direct observations of eddy turbulence at a ridge in the Southern Ocean. Geophysical Research Letters 32, L14601, doi: 10.1029/2005GL022588.

Baird RW. 1994. Foraging behaviour and ecology of transient killer whales (Orcinus orca). PhD thesis, Simon Fraser University, Vancouver, Canada.

Baird RW. 2000. The killer whale: foraging specializations and group hunting. In: Mann J, Connor RC, Tyack PL, Whitehead H (eds), Cetacean societies: field studies of dolphins and whales. Chicago: The University of Chicago Press. pp 127-153.

Baird RW, Dill LM. 1996. Ecological and social determinants of group size in transient killer whales. Behavioral Ecology 7: 408-416.

Baird RW, Whitehead H. 2000. Social organization of mammal-eating killer whales: group stability and dispersal patterns. Canadian Journal of Zoology 78: 2096-2105.

Best PB, Meÿer MA, Lockyer C. 2010. Killer whales in South African waters - a review of their biology. African Journal of Marine Science 32: 171-186.

Bigg MA, Olesiuk PF, Ellis GM, Ford JKB, Balcomb KCl. 1990. Social organization and genealogy of resident killer whales (Orcinus orca) in the coastal waters of British 
Columbia and Washington State. Reports of the International Whaling Commission Special Issue 12: 383-405.

Bolt HE, Harvey PV, Mandleberg L, Foote AD. 2009. Occurrence of killer whales in Scottish inshore waters: temporal and spatial patterns relative to the distribution of declining harbour seal populations. Aquatic Conservation: Marine and Freshwater Ecosystems 19: $671-675$.

Bowen WD. 1997. Role of marine mammals in aquatic ecosystems. Marine Ecology Progress Series 158: 267-274.

Burdin AM, Hoyt E, Filatova OA, Ivkovich T, Tarasyan K, Sato H. 2007. Status of killer whales (Orcinus orca) in eastern Kamchatka (Russian Far East) based on photo-identification and acoustic studies. Preliminary results. IWC Scientific Committee report SC/59/SM4.

Condy PR, van Aarde RJ, Bester MN. 1978. The seasonal occurrence and behaviour of killer whales Orcinus orca, at Marion Island. Journal of Zoology 184: 449-464.

Crawford RJM, Cooper J, Dyer BM, Greyling MD, Klages NTW, Ryan PG, Petersen SL, Underhill LG, Upfold L, Wilkinson W, De Villiers MS, Du Plessis S, Du Toit M, Leshoro TM, Makhado AB, Mason MS, Merkle D, Tshingana D, Ward VL, Whittington PA. 2003a. Populations of surface-nesting seabirds at Marion Island, 1994/95-2002/03. African Journal of Marine Science 25: 427-440.

Crawford RJM, Cooper J, Dyer BM. 2003b. Population of the macaroni penguin Eudyptes chrysolophus at Marion Island, 1994/95-2002/03, with information on breeding and diet. African Journal of Marine Science 25: 475-486.

Crawford RJM, Cooper J, Dyer BM, Greyling MD, Klages NTW, Nel DC, Nel JL, Petersen SL, Wolfaardt AC. 2003c. Decrease in numbers of the eastern rockhopper penguin Eudyptes chrysocome filholi at Marion Island, 1994/95-2002/03. African Journal of Marine Science 25: 487-498.

Crawford RJM, Cooper J, Du Toit M, Greyling MD, Hanise B, Holness CL, Keith DG, Nel JL, Petersen SL, Spencer K, Tshingana D, Wolfaardt AC. 2003d. Population and breeding of the gentoo penguin Pygoscelis papua at Marion Island, 1994/95-2002/03. African Journal of Marine Science 25: 463-474.

Crawford RJM, Whittington PA, Upfold L, Ryan PG, Petersen SL, Dyer BM, Cooper J. 2009. Recent trends in numbers of four species of penguins at the Prince Edward Islands. African Journal of Marine Science 31:419-426. 
de Bruyn PJN (2009) Life history studies of the southern elephant seal population at Marion Island. PhD Thesis, University of Pretoria, South Africa.

de Villiers MS, Cooper J. 2008. Conservation and management. In: Chown SL, Froneman PW (eds), The Prince Edward Islands: Land-sea interactions in a changing ecosystem. Stellenbosch: Sun Media.

Dahlheim ME, Ellifrit DK, Swenson JD. 1997. Killer whales of southeast Alaska: A catalogue of photo-identified individuals. Seattle: Day Moon Press.

Dahlheim ME, Schulman-Janiger A, Black N, Ternullo R, Ellifrit D, Balcomb KC III. 2008. Eastern temperate North Pacific offshore killer whales (Orcinus orca): occurrence, movements, and insights into feeding ecology. Marine Mammal Science 24: 719-729.

du Plessis CJ, van Heezik YM, Seddon PJ. 1994. Timing of king penguin breeding at Marion Island. Emu 94: 216-219.

Ford JKB, Ellis GM. 2006. Selective foraging by fish-eating killer whales Orcinus orca in British Columbia. Marine Ecology Progress Series 316: 185-199.

Ford JKB, Ellis GM, Barrett-Lennard LG, Morton AB, Palm RS, Balcomb KC. 1998. Dietary specialization in two sympatric populations of killer whales (Orcinus orca) in coastal British Columbia and adjacent waters. Canadian Journal of Zoology 76: 1456-1471.

Guinet C. 1992. Comportement de chasse des orques (Orcinus orca) autour des iles Crozet. Canadian Journal of Zoology 70: 1656-1667 (in French, with English summary).

Guinet C, Jouventin P, Weimerskirch H. 1992. Population changes, movements of southern elephant seals in Crozet and Kerguelen Archipelagos in the last decades. Polar Biology 12: $349-356$.

Guinet C, Barrett-Lennard LG, Loyer B. 2000. Co-ordinated attack behavior and prey sharing by killer whales at Crozet Archipelago: strategies for feeding on negatively-buoyant prey. Marine Mammal Science 16: 829-834.

Herman DP, Burrows DG, Wade PR, Durban JW, Matkin CO, Leduc RG, Barrett-Lennard LG, Krahn MM. 2005. Feeding ecology of eastern North Pacific killer whales Orcinus orca from fatty acid, stable isotope, and organochlorine analyses of blubber biopsies. Marine Ecology Progress Series 302: 275-291.

Hoelzel AR. 1991. Killer whale predation on marine mammals at Punta Norte, Argentina; food sharing, provisioning and foraging strategy. Behavioral Ecology and Sociobiology 29: 197-204. 
Hoelzel AR, Dahlheim M, Stern SJ. 1998. Low genetic variation among killer whales (Orcinus orca) in the eastern North Pacific and genetic differentiation between foraging specialists. Journal of Heredity 89: 121-128.

Hofmeyr GJG, Bester MN, Makhado AB, Pistorius PA. 2006. Population changes in Subantarctic and Antarctic fur seals at Marion Island. South African Journal of Wildlife Research 36: 55-68.

Hofmeyr GJG, Bester MN, Pistorius PA, Mulaudzi TW, de Bruyn PJN, Ramunasi AJ, Tshithabane NH, Mclntyre T, Radzilani PM. 2007. Median pupping date, pup mortality and sex ratio of fur seals at Marion Island. South African Journal of Wildlife Research 37: 1-8.

Hoyt E. 1990. Orca, the whale called killer (3rd edn). Camden East, Ontario: Camden House.

Iñíguez MA. 2001. Seasonal distribution of killer whales (Orcinus orca) in Northern Patagonia, Argentina. Aquatic Mammals 27: 154-161.

Iñíguez MA, Tossenberger VP, Gasparrou C. 2002. Cooperative hunting and prey handling of killer whales in Punta Norte, Patagonia, Argentina. In: Proceedings of the fourth international orca symposium and workshops. Villiers en Bois, France: Centre National de la Recherche Scientifique. p. 85.

Jefferson TA, Stacey PJ, Baird RW. 1991. A review of killer whale interactions with other marine mammals: predation to co-existence. Mammal Review 21: 151-180.

Keith M, Bester MN, Bartlett PA, Baker D. 2001. Killer whales (Orcinus orca) at Marion Island, Southern Ocean. African Zoology 36: 163-175.

Kerley GIH. 1983. Relative population sizes and trends, and hybridisation of fur seals Arctocephalus tropicalis and A. gazella at Prince Edward Islands, Southern Ocean. South African Journal of Zoology 18: 388-392.

Kerley GIH. 1985. Pup growth in the fur seals Arctocephalus tropicalis and A. gazella on Marion Island. Journal of Zoology 205: 315-324.

Kock KH, Purves MG, Duhamel G. 2006. Interactions between cetacean and fisheries in the Southern Ocean. Polar Biology 29: 379-388.

Kirkman SP, Bester MN, Hofmeyr GJG, Jonker FC, Pistorius PA, Owen R, Strydom N. 2004. Variation in the timing of the breeding haulout of female southern elephant seals at Marion Island. Australian Journal of Zoology 52: 379-388. 
Krahn MM, Pitman RL, Burrows DG, Herman DP, Pearce RW. 2008. Use of chemical tracers to assess diet and persistent organic pollutants in Antarctic Type C killer whales. Marine Mammal Science 24:643-663.

Laws RM. 1956. The elephant seal (Mirounga leonina Lin) II General, social and reproductive behaviour. Falkland Islands Dependencies Survey Scientific Reports 13: 1-88.

Lopez JC, Lopez D. 1985. Killer whales (Orcinus orca) of Patagonia, and their behavior of intentional stranding while hunting nearshore. Journal of Mammalogy 66: 181-183.

Matkin CO, Ellis G, Olesiuk P, Saulitis E. 1999. Association patterns and inferred genealogies of resident killer whales, Orcinus orca, in Prince William Sound, Alaska. Fishery Bulletin 97: 900-919.

McMahon CR, Bester MN, Hindell MA, Brook BW, Bradshaw CJA. 2009. Shifting trends: detecting environmentally mediated regulation in long-lived marine vertebrates using time-series data. Oecologia 159: 69-82.

Nichol LM, Shackleton DM (1996) Seasonal movements and foraging behaviour of northern resident killer whales (Orcinus orca) in relation to the inshore distribution of salmon (Oncorhynchus spp.) in British Columbia. Canadian Journal of Zoology 74: 983-991.

Pistorius PA, Taylor FE, Louw C, Hanise B, Bester MN, de Wet C, du Plooy A, Green N, Klasen S, Podile S, Schoeman J. 2002. Distribution, movement, and estimated population size of killer whales at Marion Island, December 2000. South African Journal of Wildlife Research 32: 86-92.

Pitman RL, Durban JW. 2010. Killer whale predation on penguins in Antarctica. Polar Biology doi: 10.1007/s00300-010-0853-5.

Pitman RL, Ensor P. 2003. Three forms of killer whales (Orcinus orca) in Antarctic waters. Journal of Cetacean Research and Management 5: 131-139.

Reisinger RR, de Bruyn PJN, Bester MN. In review. Mark-recapture abundance estimates of killer whales at Subantarctic Marion Island. Aquatic Biology.

Roux J-P. 1986. Le cycle d'abondance des orques, Orcinus orca, aux îles Saint Paul et Amsterdam. Mammalia 50: 5-8 (in French, with English summary).

Similä T, Holst JC, Christensen I. 1996. Occurrence and diet of killer whales in northern Norway: seasonal patterns relative to distribution and abundance of Norwegian spring-spawning herring. Canadian Journal of Fisheries and Aquatic Science 53: 769779. 
Springer AM, Estes JA, van Vliet GB, Williams TM, Doak DF, Danner EM, Forney KA, Pfister B. 2003. Sequential megafaunal collapse in the North Pacific Ocean: An ongoing legacy of industrial whaling? Proceedings of the National Academy of Science 100: 12223-12228.

Tosh CA, de Bruyn PJN, Bester MN. 2008. Preliminary analysis of the social structure of killer whales, Orcinus orca, at subantarctic Marion Island. Marine Mammal Science 24: 929940.

Wilkinson IS, Bester MN. 1990. Duration of post-weaning fast and local dispersion in the southern elephant seal, Mirounga leonina, at Marion Island. Journal of Zoology 222: 591-600.

Williams AJ, Dyer BM, Randall RM, Komen J. 1990. Killer whales Orcinus orca and seabirds: "play", predation and association. Marine Ornithology 18: 37-41.

Williams AJ, Petersen SL, Goren M, Watkins BP. 2009. Sightings of killer whales Orcinus orca from longline vessels in South African waters, and consideration of the regional conservation status. African Journal of Marine Science 31: 81-86. 
Table 1

Post-hoc Mann-Whitney pair-wise comparisons for significant differences between monthly sighting rates of killer whales at Rockhopper Bay,

Marion Island. $p$ values shown. Grey shading indicates $p<0.05$, bold type indicates $p<0.01$

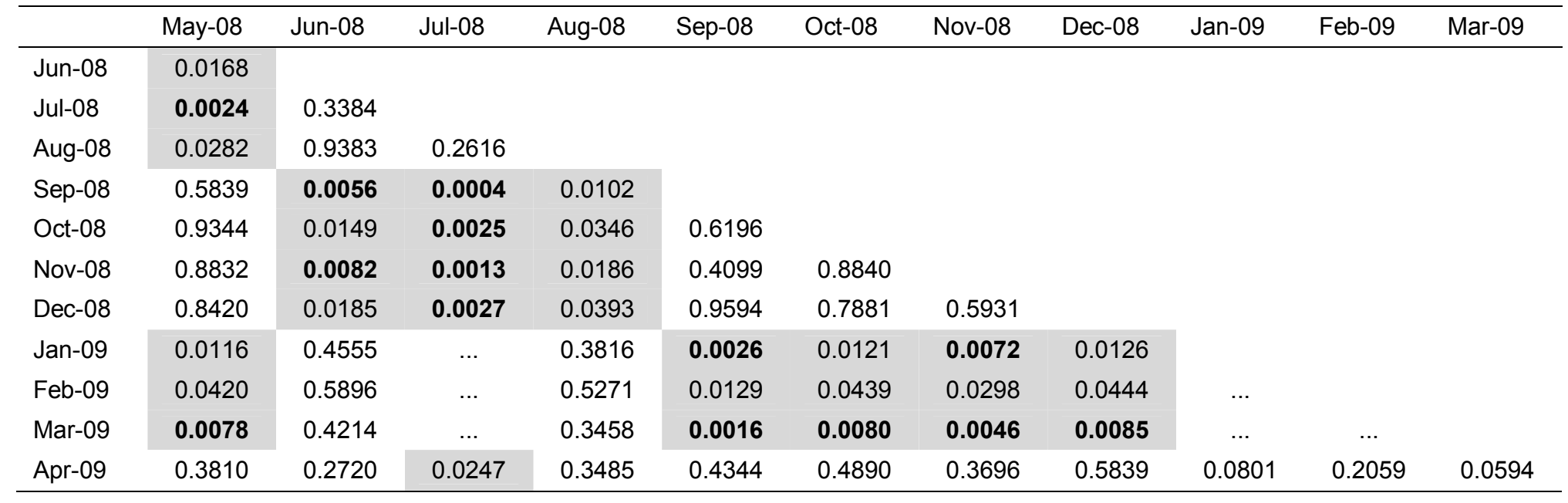




\section{FIGURES}

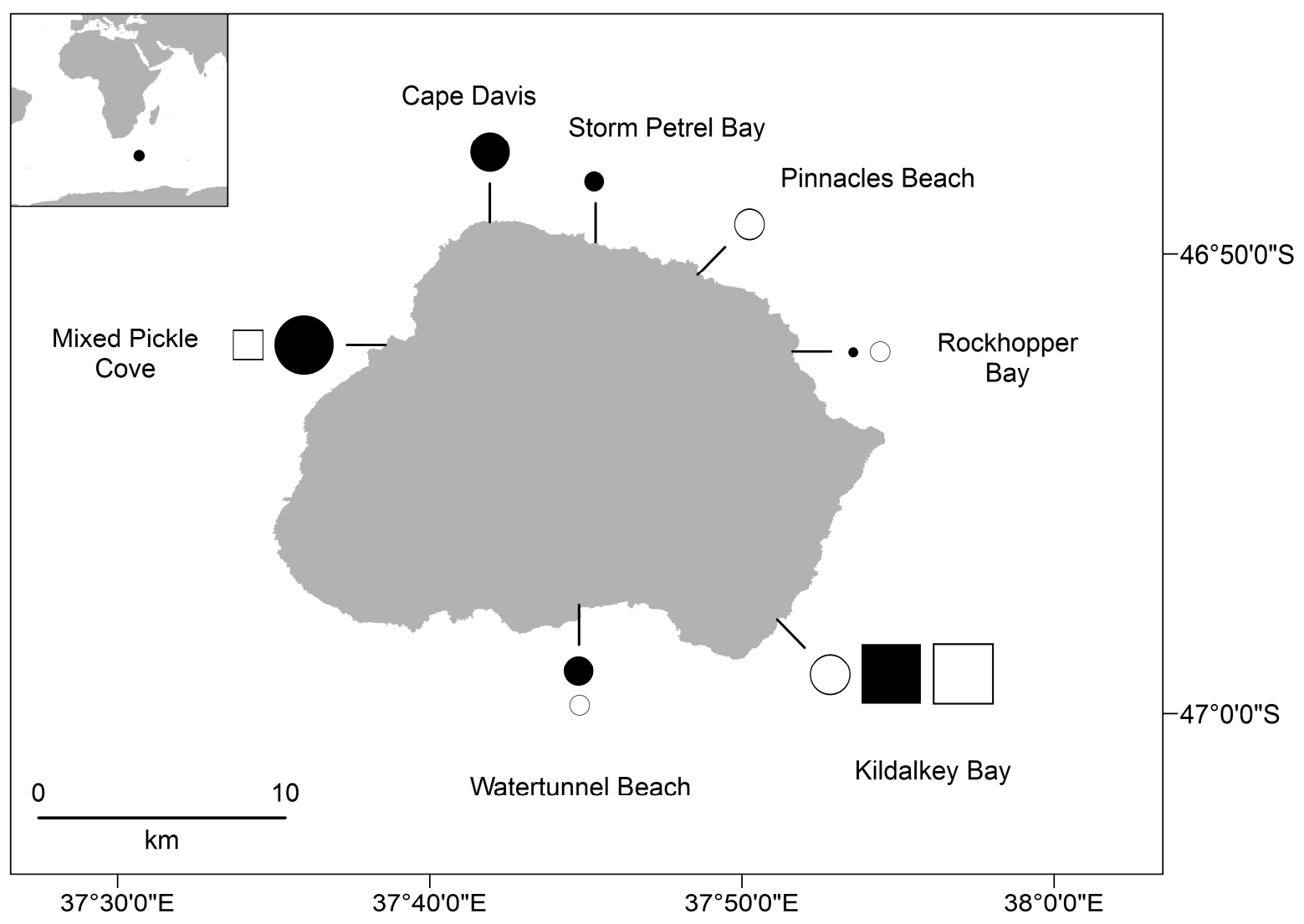

Figure 1

Map of Marion Island, Southern Indian Ocean, showing the locations (Mixed Pickle Cove, Cape Davis, Storm Petrel Bay, Pinnacles Beach, Rockhopper Bay, Kildalkey Bay and Watertunnel Beach) where dedicated killer whale observations were made and the breeding population sizes of fur seals $(\mathbf{O})$, elephant seals $(\bigcirc)$, king penguins $(\boldsymbol{\square})$ and macaroni penguins $(\square)$ at these locations. Symbol sizes represent relative population sizes. 

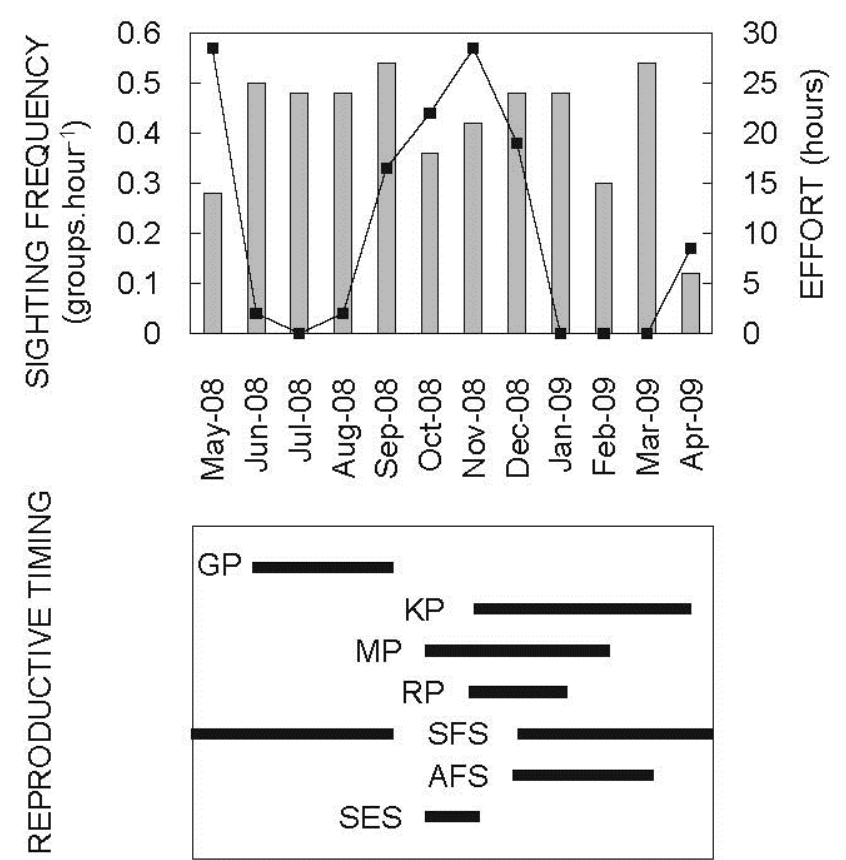

Figure 2

Monthly sighting frequency of killer whales (black line) and observation effort (grey bars) at Rockhopper Bay, Marion Island, between May 2008 and April 2009, as well as the reproductive timing (median adult arrival to median chick crèching date for penguins and median pupping to median weaning date for seals) of gentoo penguins (GP; Crawford et al 2003d), king penguins (KP; du Plessis et al. 1994), macaroni penguins (MP; Crawford et al. 2003b), rockhopper penguins (RP; Crawford et al. 2003c), Subantarctic fur seals (SAFS; Hofmeyr et al. 2007), Antarctic fur seals (AFS; Hofmeyr et al. 2007) and southern elephant seals (SES; Kirkman et al. 2004). 


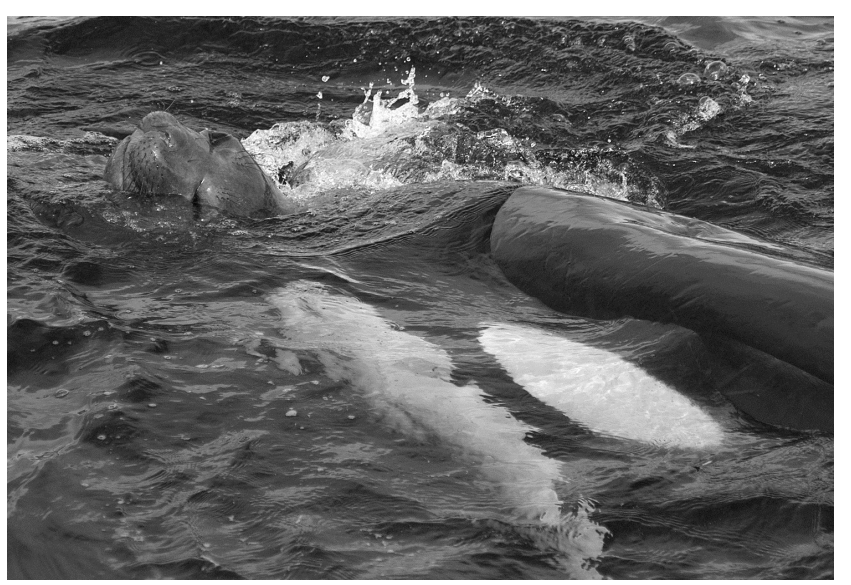

Figure 3

Photograph showing a killer whale predating an elephant seal at Marion Island. Photograph by RR Reisinger.

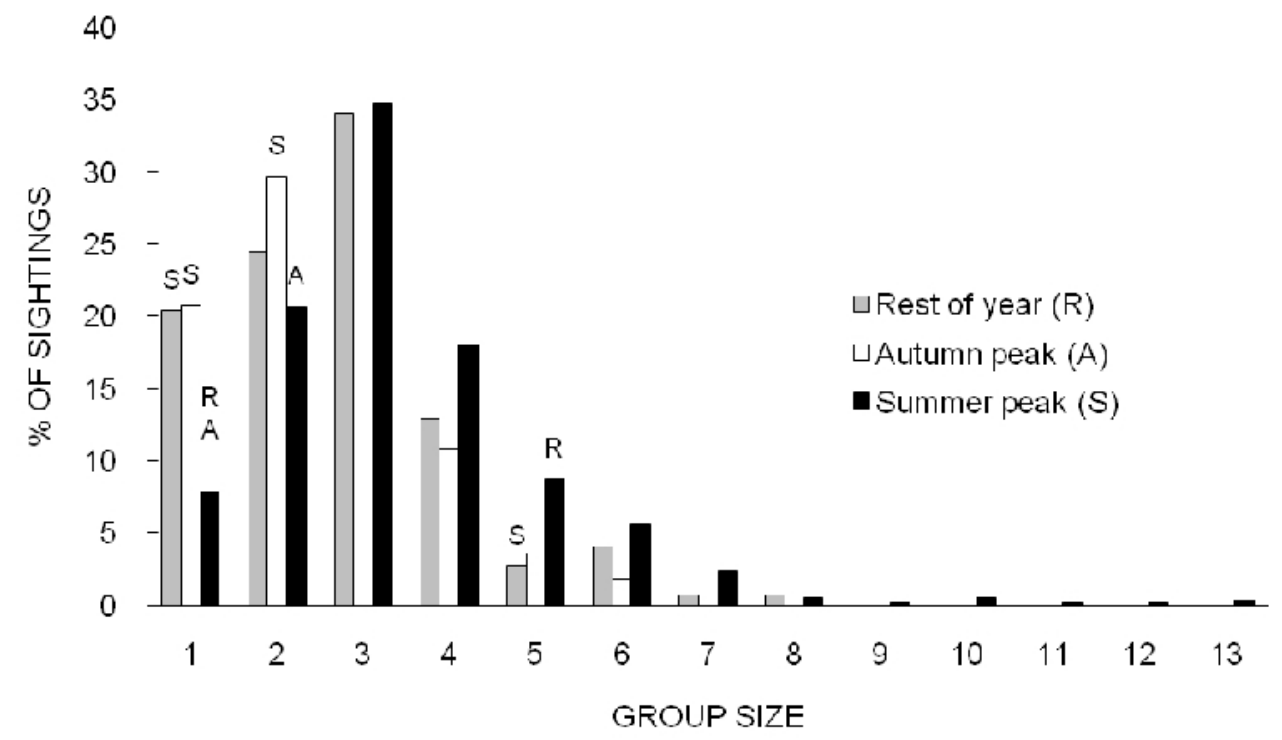

Figure 4

Group size frequency distribution of killer whales at Marion Island between April 2006 and April 2009. "Rest of year" represents sightings from January-March and June-August, "Autumn peak" represents sightings from April-May, and "Summer peak" sightings from September-December. Letters above a bar indicate a significant difference $(p<0.05)$ between the group size sighting frequency in that period and the period corresponding to the letter. 